\title{
Students' Perceptions and Continuous Intention to Use E- Learning Systems: The Case of Google Classroom.
}

\author{
https://doi.org/10.3991/ijet.v15i11.12683 \\ Kwame Ansong-Gyimah \\ University of Education, Winneba, Ghana \\ kagyimah@uew.edu.gh
}

\begin{abstract}
Higher institutions are steadily advancing in facilitating teaching and learning on e-learning systems. Google Classroom is a very popular e-learning system that is been adopted by many African universities. Yet, compared to others, relevant studies with regards to Google Classroom is inadequate. This quantitative survey paper examines the predictors of continuous intention to use Google Classroom. Responses from 749 students in three Ghanaian universities were analyzed using both descriptive and Partial Least Square Structural Equation Modelling techniques. From the findings, Attitude towards Use mediated the impact of Perceived Usefulness and Perceived Ease of Use on Continuous Intention to Use Google Classroom. Computer literacy courses for adult learners as well as enhanced usability features for visually impaired users has been recommended to relevant stakeholders.
\end{abstract}

Keywords-E-learning, google classroom, continuous intention

\section{$1 \quad$ Introduction}

In recent years, the setting up of online learning systems in higher education has increased considerably. This is because these online learning systems offer many advantages over the traditional classroom environment. Among others, these systems enable leaners to freely access learning materials, interact with instructors and other learners via the internet $[1,2]]$. Perhaps, the most influential advantage is the flexibility and adaptability they permit for working students [3].

Google Classroom is one of such platforms that has gained popularity in higher educational institutions particularly in Africa. It is a course management software designed to simplify class organization and improve student-teacher communication [4]. With Google Classroom, students have the opportunity to share resources among themselves, submit assignments and witness their progress. Accordingly, Google Classroom is also beneficial for teachers. It enables them to assess students' class work and provide appropriate feedback [5]. Consequently, relevant studies have associated Google Classroom with higher student satisfaction and enthusiasm [6].

However, the successful implementation of Google Classroom is dependent on students' perceptions and experiences [1]. In other words, when students do not perceive the system as useful, they will be unwilling to accept and use it. Therefore, it is a waste 
of time and resources to implement systems that are unaccepted or perceived negatively. It becomes very imperative that higher educational institutions that seek to implement systems such as Google Classroom are well informed about students' perceptions.

As a result, this paper studies students' perceptions on Google Classroom. It adopts the Technology Acceptance Model (TAM) [7] to assess how these perceptions affect students' continuous intention to use Google Classroom. The next section reviews relevant literature. Section three presents the theoretical framework and hypotheses development. Whereas section 4 presents the methods and data analysis, section 5 discusses the outcome of the data analysis.

\section{$2 \quad$ Literature Review}

Literature related to e-learning systems is abundant. A number of studies have examined acceptance patterns of various e-learning platforms including Moodle and Blackboard $[8,9,10]$. However, papers that focus specifically on Google Classroom is inadequate [4]. To augment literature in this discipline, [1] examined the factors that influence Google Classroom implementation with the Unified Theory of Acceptance and Use of Technology (UTAUT) as a founding theory. The result led the authors to conclude that Google Classroom promotes self-directed learning and improves cognitive skills. This position is further emphasized by [11]. [11] further adds that factors including usefulness and ease of use affect students' satisfaction on the platforms. Similarly, [4] and [12] posit that these factors also predict students' behavioral intentions to use Google Classroom. Expanding [4]'s work, [13] indicate that social influence and connected classroom climate all contribute to intentions to use Google Classroom. Moreover, [14] is of the view that Google Classroom can be an effective active learning tool.

A rigorous synthesis of the literature indicates that existing studies have rather predominantly focused on behavioral intentions to use Google Classroom. Studies that measures students' continuous use of Google Classroom are missing. [15] point out that intentions do not always lead to continuous usage of a system. It is possible that students may form intentions to use Google Classroom yet may not continuously use it for learning. Hence, it is important to understand which factors predict students' continuous use intention of Google Classroom. This will enable institutions to stimulate students' usage of Google Classroom platform.

\section{Theoretical Framework}

There are many models that explain technology acceptance and use. The Technology Acceptance Model (TAM) developed by [7] is one of such models that is very popular in information systems research. TAM is an extension of the Theory of Reasoned Action [16]. TAM argues that behavioral intention to use Google Classroom is informed by Perceived Usefulness (PU) and Perceived Ease of Use (PEOU). Perceived Usefulness is described as the belief that Google Classroom will enhance one's academic 
productivity. Perceived Ease of Use is the extent to which a student believes that Google Classroom require less effort to use. [17] asserts that researchers must extend existing theories with relevant constructs to reflect the rapid changes in technology acceptance research. Consequently, this paper extends the model with Attitude Towards Use (ATT). Attitude Towards Use is defined as a student's affective feeling towards the use of Google Classroom. In line with the aims of this paper, Behavioral Intention in the original model is replaced with Continuous Use Intention. Continuous Use Intention is a student's intention to continue using Google Classroom. Ultimately, this paper examines the effects of Perceived Usefulness and Perceived Ease of Use on Attitude Towards Use. Finally, it investigates the relationship between Attitude Towards Use and Continuous Use Intention. Based on this, the following hypothesis will be tested:

- H1: Perceived Usefulness significantly affects Attitude Towards Use.

- H2: Perceived Ease of Use significantly affects Attitude Towards Use.

- H3 Attitude Towards Use significantly affects Continuous Use Intention.

\section{$4 \quad$ Research Methods}

A quantitative survey methodology was employed for the study. An online questionnaire designed using Google Forms gathered students' views on the use of Google Classroom. A cover letter outlined the purpose of the study and an assurance of confidentiality. The questionnaire also requested only relevant demographic information from respondents to ensure anonymity. Finally, students' perceptions on (i) Usefulness (ii) Ease of Use (iii) Attitude and (iv) continuous intention to use Google Classroom were solicited. All questions were designed as reflective on a 5-point Likert-scale ranging from 1 ("Strongly Disagree") to 5 ("Strongly Agree").

In all, 749 out of $820(91.3 \%)$ students from three universities in Ghana responded to the electronic questionnaire. The participants in this study were all students (undergraduate and graduate) who had used Google Classroom throughout the semester. Convenience sampling was used to select respondents.

\section{$5 \quad$ Data Analysis}

Aside the descriptive analysis of the various demographics, Partial Least Square Structural Equation Modelling (PLS-SEM) was adopted to evaluate the research model. Unlike other approaches, PLS-SEM is robust to multivariate errors and appropriate for exploratory research such as the present study. The measurement model was evaluated in terms of item loadings, internal consistency, convergent and discriminant validity as preferred by [18]. Bootstrap (500 samples) was adopted to assess the structural model.

\section{$5.1 \quad$ Descriptive statistics}

Table 1 indicates a summary of the respondents' demographics. From the table $86 \%$ were males whereas the remaining $(14 \%)$ were females. Furthermore, a large majority 
(85\%) were between 18 and 30 years; $14 \%$ were 31 to 40 years and $1 \%$ were above 40 years. With regard to level of education, $96 \%$ were undergraduates whilst $3 \%$ were postgraduate students.

Table 1. Respondents' Demographics

\begin{tabular}{|l|l|c|c|}
\hline \multicolumn{1}{|c|}{ Item } & \multicolumn{1}{|c|}{ Value } & Frequency & Percentage \\
\hline \multirow{3}{*}{ Agender } & Female & 644 & $86 \%$ \\
\cline { 2 - 4 } & Male & 105 & $14 \%$ \\
\hline \multirow{3}{*}{ Education Level } & $18-30$ & 635 & $85 \%$ \\
\cline { 2 - 4 } & $31-40$ & 106 & $14 \%$ \\
\cline { 2 - 4 } & Above 40 & 8 & $1 \%$ \\
\hline & Undergraduate & 721 & $96 \%$ \\
\cline { 2 - 4 } & Postgraduate & 28 & $4 \%$ \\
\hline
\end{tabular}

Descriptive analysis was also applied to students' access to course material, quality of work and as to whether they will recommend Google Classroom to be used in all their courses. With regards to access to course materials, Figure 1 shows that $82 \%$ strongly agreed or agreed that the use of Google Classrooms had increased their access to course materials. Moreover, students' views about whether Google Classroom improved their quality of work was assessed. From figure 2, a combined 79\% strongly agreed or agreed that Google Classroom improved their quality of work. Finally, $88 \%$ recommended Google Classroom to be used for all their courses whereas $12 \%$ answered no.

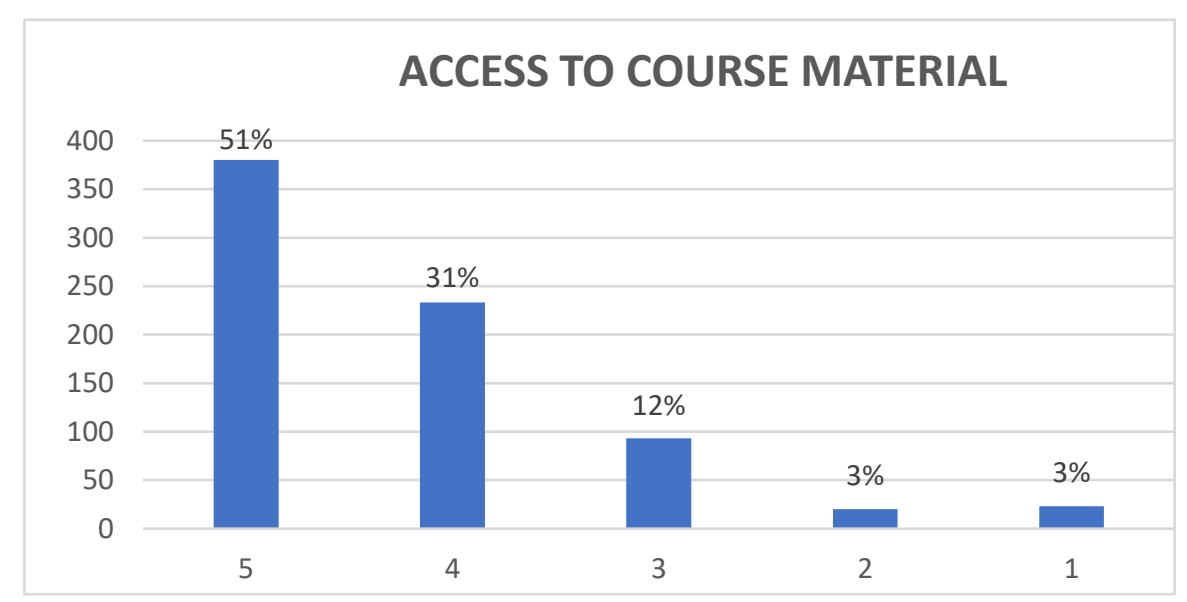

Fig. 1. Access to Course Materials. 


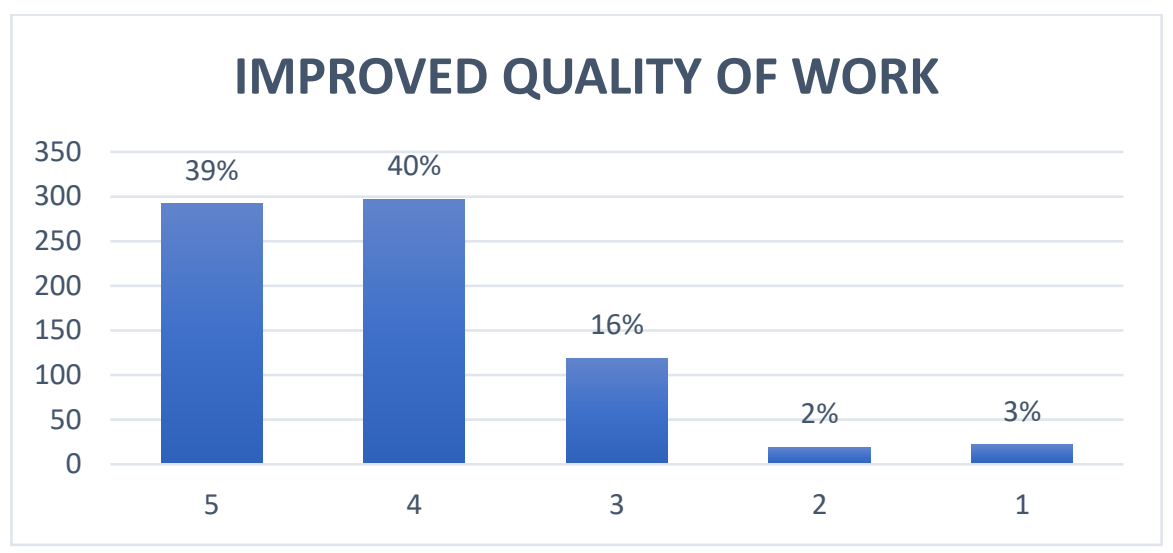

Fig. 2. Improved Quality of Work

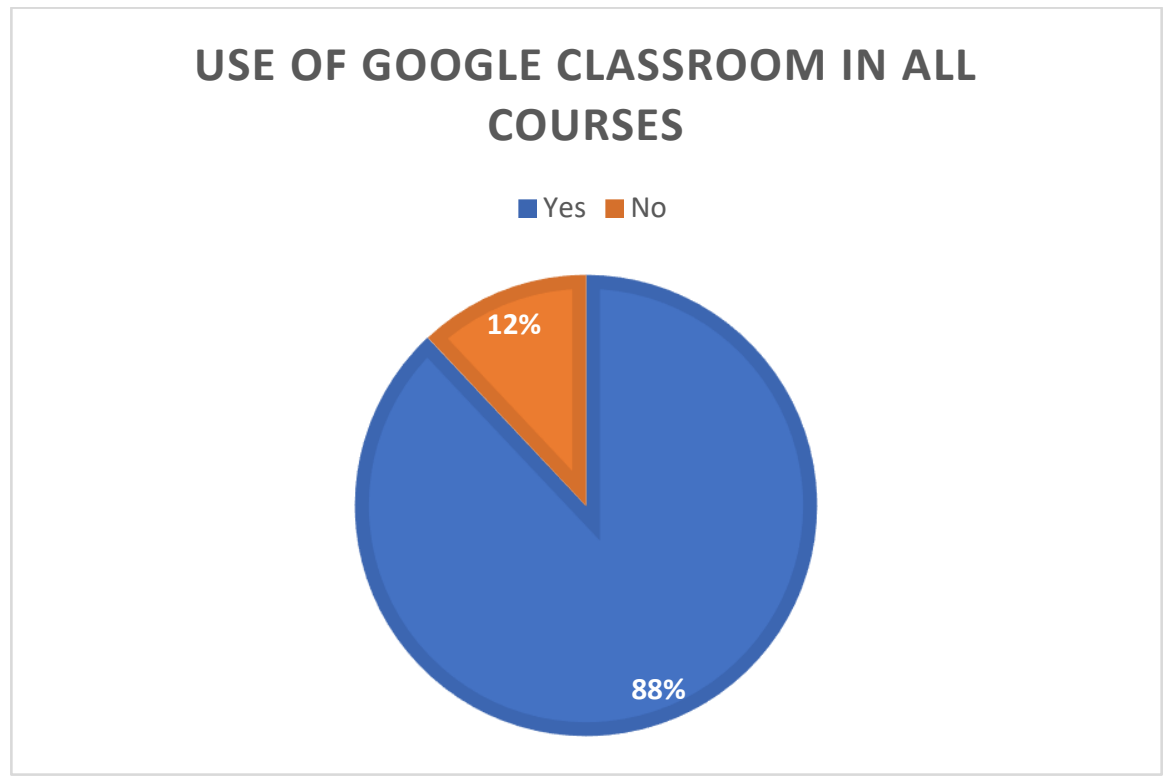

Fig. 3. Use of Google Classroom for all Courses.

\subsection{Measurement model}

The reliability of the question items was measure by juxtaposing the results to [19]'s threshold of 0.7. Composite reliability and the traditional Cronbach's Alpha was used to assess internal consistency. Internal consistency requirements are met when the values for Composite reliability and the traditional Cronbach's Alpha are above 0.7. In addition, the Average Variance Extracted was used to assess convergent validity. AVEs greater than 0.5 is preferable. Table 2 indicates that the requirements for internal consistency and convergent validity were met. [20]'s criterion was adopted to measure 
discriminant validity. According to the authors, the square root of AVE for each variable must exceed all other latent variables. The highlighted diagonal figures in table 2 indicates discriminant validity was established.

Table 2. Construct Reliability and Validity

\begin{tabular}{|l|c|c|c|c|c|c|c|c|}
\hline & CA & rho_A & CR & AVE & ATT & CONT & PEOU & PU \\
\hline ATT & 0.763 & 0.767 & 0.863 & 0.679 & 0.824 & & & \\
\hline CONT & 0.732 & 0.733 & 0.849 & 0.653 & 0.667 & 0.808 & & \\
\hline PEOU & 0.686 & 0.687 & 0.827 & 0.615 & 0.679 & 0.721 & 0.784 & \\
\hline PU & 0.698 & 0.720 & 0.817 & 0.533 & 0.589 & 0.611 & 0.578 & 0.730 \\
\hline
\end{tabular}

\subsection{Structural model}

The bootstrap (500 samples) technique was adopted to examine the hypothesized relationships. Using PLS path analysis technique and a one-tailed t-test, a predicted relationship was supported when the p-value is less than 0.05. [21]'s effect sizes (f 2) was implemented to determine if the effect of a construct on another was relevant (i.e. $<0.02$ ), small (i.e. 0.02), medium (i.e. 0.15) or large (i.e. 0.35). From the results, all predicted relationships were significant. The model explained $51.6 \%$ and $44.5 \%$ of the variances in Attitude Towards Use and Continuous Use Intention respectively. Moreover, whereas Perceived Usefulness (f $2=0.121$ ) had a medium effect, Perceived Ease of Use (f $2=0.358$ ) had a large effect on Attitude Towards Use. Finally, the effect of Attitude Towards Use (f $2=0.801$ ) on Continuous Use Intention was large. Table 3 gives a detailed summary of the results.

Table 3. Significance of Path Coefficient

\begin{tabular}{|l|c|c|c|c|c|c|}
\hline & $\begin{array}{c}\text { Original Sam- } \\
\text { ple (O) }\end{array}$ & $\begin{array}{c}\text { Sample } \\
\text { Mean (M) }\end{array}$ & $\begin{array}{c}\text { Standard De- } \\
\text { viation } \\
(\mathbf{S T D E V})\end{array}$ & $\begin{array}{c}\text { T Statistics } \\
(|\mathbf{O} / \mathbf{S T D E V}|)\end{array}$ & P Values & $\begin{array}{c}\text { Effect Size } \\
\left(\boldsymbol{f}^{\mathbf{2}}\right)\end{array}$ \\
\hline ATT -> CONT & 0.667 & 0.670 & 0.034 & 19.813 & 0.000 & 0.801 \\
\hline PEOU -> ATT & 0.508 & 0.509 & 0.049 & 10.400 & 0.000 & 0.358 \\
\hline PU -> ATT & 0.295 & 0.297 & 0.049 & 6.065 & 0.000 & 0.121 \\
\hline
\end{tabular}

Figure 4 is a graphically depiction of the results of the structural model analysis. 


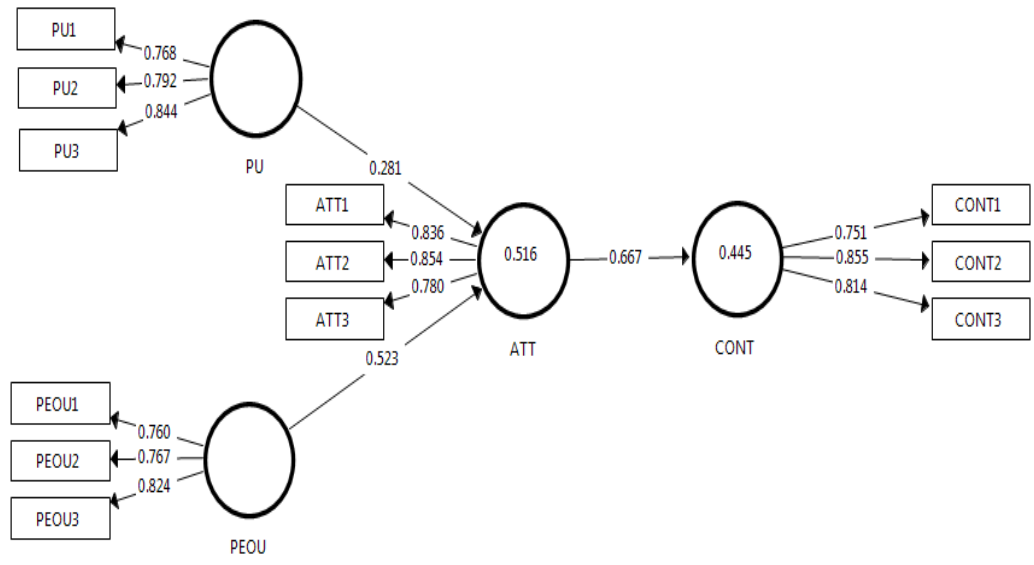

Fig. 4. PLS Analysis of Structural Model

\section{Discussion}

From the results, all the predicted relationships were significant. Perceived Usefulness and Perceived Ease of Use were significant in predicting users Attitude towards Google Classroom use. It is however clear that when students indicate that Google Classroom is useful, they form positive judgements about its use. Similarly, students develop positive affective feelings towards Google Classroom when they find it easy to use. These findings are consistent with [22] and [23]. Moreover, Attitude towards Use was found to influence Continuous Use Intention. That is, positive judgement towards Google Classroom leads to users' continuous use. Recently, it can be argued that there are more digital natives today than ever, and consequently, a fundametal shift in the thinking and use of ICTs has occcured. As the population of digital natives swells, so does users form favorable attitudes towards adoption and use of ICTs. It is however recommended that institutions continually organized computer literacy courses for particularly older students to hasten their adoption and use of ICTs. Relatedly, designers of Google Classroom platform should enhance the usability features to make it much more easier to use.

\section{Conclusion}

Adoption of Google Classroom platform as an educational tool in higher institutions continue to increase. Meanwhile, relevant studies have sought to focus more on preadoption factors rather than predictors of continuous use. Using a survey approach, this study examined the factors that influence students' continuous intention to use Google Classroom Platform. PLS-SEM was adopted to estimate reponses from 749 students. 
The research model underlined that Attitude towards Use mediates the effects of Perceived Usefulness and Perceived Ease of Use on Continuous Intention to Use. However, the results are difficult to generalize since comvenience sampling technique was used to select the respondents. In addition, although the study admits that moderators such gender may influence the results, the research model failed to include such moderators.

\section{$8 \quad$ References}

[1] Jakkaew, P., \& Hemrungrote, S. (2017). The use of UTAUT2 model for understanding student perceptions using Google Classroom: A case study of introduction to information technology course. In 2017 International Conference on Digital Arts, Media and Technology (ICDAMT) (pp. 205-209). https://doi.org/10.1109/icdamt.2017.7904962

[2] Denizalp, H., \& Ozdamli, F. (2019). Determination of Student Opinions on Usage of Social Media and Mobile Tools in Student-Teacher, Student-Student Communication. International Journal Of Emerging Technologies In Learning (IJET), 14(22), pp. 19-28. doi: https://doi.org/10.3991/ijet.v14i22.11745

[3] Rimale, Z., El Habib, B. L., \& Tragha, A. (2016). A Brief Survey and Comparison of mLearning and e-Learning. International Journal of Computer Networks and Communications Security, 4(4), 89.

[4] Al-Maroof, R. A. S., \& Al-Emran, M. (2018). Students Acceptance of Google Classroom: An Exploratory Study using PLS-SEM Approach. International Journal of Emerging Technologies in Learning, 13(6), 112-123. https://doi.org/10.3991/ijet.v13i06.8275

[5] Iftakhar, S. (2016). Google classroom: what works and how? Journal of Education and Social Sciences, 3(1), 12-18.

[6] Ciriaco, M. A., dos Santos, J., Moreira, F., \& Gomes, A. S. (2019). Health Student Using Google Classroom: Satisfaction Analysis. In Learning Technology for Education Challenges: 8th International Workshop, LTEC 2019, Zamora, Spain, July 15--18, 2019, Proceedings (p. 58). https://doi.org/10.1007/978-3-030-20798-4 6

[7] Davis, F. D. (1989). Perceived usefulness, perceived ease of use, and user acceptance of information technology. MIS Quarterly, 13(3), 319-340. https://doi.org/10.2307/249008

[8] Binyamin, S. S., Rutter, M. J., \& Smith, S. (2019). Extending the Technology Acceptance Model to Understand Students' use of Learning Management Systems in Saudi Higher Education. International Journal of Emerging Technologies in Learning, 14(3). https://doi.org/10.3991/ijet.v14i03.9732

[9] Khamaruddin, P. F. M., Sauki, A., Kadri, N. H. O., Rahim, A. N. C. A., \& Kadri, A. (2017). Technology Acceptance Model Analysis on Students' Behavioral Intention of Using Moodle for FYP. In 2017 7th World Engineering Education Forum (WEEF) (pp. 724-727). https://doi.org/10.1109/weef.2017.8467082

[10] Yeou, M. (2016). An investigation of students' acceptance of Moodle in a blended learning setting using technology acceptance model. Journal of Educational Technology Systems, 44(3), 300-318. https://doi.org/10.1177/0047239515618464

[11] Hemrungrote, S., Jakkaew, P., \& Assawaboonmee, S. (2017). Deployment of Google Classroom to enhance SDL cognitive skills: A case study of introduction to information technology course. In 2017 International Conference on Digital Arts, Media and Technology (ICDAMT) (pp. 200-204). https://doi.org/10.1109/icdamt.2017.7904961 
[12] Wijaya, A. (2016). Analysis of factors affecting the use of Google Classroom to support lectures. In The 5th International Conference on Information Technology and Engineering Application (ICIBA2016).

[13] Yang, H. H., Feng, L., \& MacLeod, J. (2019). Understanding college students' acceptance of cloud classrooms in flipped instruction: integrating UTAUT and connected classroom climate. Journal of Educational Computing Research, 56(8), 1258-1276. https://doi.org/ $10.1177 / 0735633117746084$

[14] Shaharanee, I. N. M., Jamil, J. M., \& Rodzi, S. S. M. (2016). The application of Google Classroom as a tool for teaching and learning. Journal of Telecommunication, Electronic and Computer Engineering (JTEC), 8(10), 5-8. https://doi.org/10.1063/1.4960909

[15] Wiafe, I., Nakata, K., \& Gulliver, S. (2014). Categorizing users in behavior change support systems based on cognitive dissonance. Personal and Ubiquitous Computing, 18(7), 16771687. https://doi.org/10.1007/s00779-014-0782-3

[16] Fishbein, M., \& Ajzen, I. (1975). Belief, attitude, intention and behavior: An introduction to theory and research. Addison-Wesley, Reading, MA.

[17] Bagozzi, R. P. (2007). The legacy of the technology acceptance model and a proposal for a paradigm shift. Journal of the Association for Information Systems, 8(4), 3.

[18] Coltman, T., Devinney, T. M., Midgley, D. F., \& Venaik, S. (2008). Formative versus reflective measurement models: Two applications of formative measurement. Journal of Business Research, 61(12), 1250-1262. https://doi.org/10.1016/j.jbusres.2008.01.013

[19] Bagozzi, R. P., Yi, Y., \& Phillips, L. W. (1991). Assessing construct validity in organizational research. Administrative Science Quarterly, 36(3), 421-458. https://doi.org/10. 2307/2393203

[20] Fornell, C., \& Larcker, D. F. (1981). Evaluating structural model with unobserved variables and measurement errors. Journal of Marketing Research, 18(1), 39-50.

[21] Cohen, J. (1988). Statistical Power Analysis for the Behavioral Sciences, 2nd Edition. L. Elbaum Associates, Hillside, NJ

[22] Jović, M., Stankovic, M. K., \& Neskovic, E. (2017). Factors affecting students' attitudes towards e-learning. Management: Journal of Sustainable Business and Management Solutions in Emerging Economies, 22(2), 73-80 https://doi.org/10.7595/10.7595/management.fon.2017.0016

[23] Kisanga, D. H. (2016). Determinants of teachers' attitudes towards e-learning in Tanzanian higher learning institutions. The International Review of Research in Open and Distributed Learning, 17(5). https://doi.org/10.19173/irrodl.v17i5.2720

\section{Author}

Dr. Kwame Ansong-Gyimah is an Instructional Technologist who focuses his research studies on technology in education. He is a Lecturer and Head of Department of the Information Technology Education Department at the Kumasi Campus of the University of Education, Winneba.

Article submitted 2019-12-11. Resubmitted 2020-02-03. Final acceptance 2020-02-05. Final version published as submitted by the authors. 